\title{
DESKRIPSI PERSEPSI MASYARAKAT TERHADAP PENGELOLAAN LIMBAH TAHU DAN PEMANFATAANYA DI KECAMATAN KARANGPLOSO KABUPATEN MALANG
}

\author{
Purwaning Budi Lestari' ${ }^{1)}$, Moh. Ali Muarifudin ${ }^{2)}$, Triasih Wahyu $\mathbf{H}^{3)}$ \\ IKIP Budi Utomo \\ ${ }^{1)}$ Purwaning.budilestari@ gmail.com,${ }^{2)}$ aliamzeta@ gmail.com,${ }^{3)}$ triasihibu@ gmail.com
}

\begin{abstract}
The purpose of this study was to describe the public's perception of tofu waste management and its utilization in Malang Regency. The type of research used is survey research which is analyzed using descriptive statistics by looking at the percentage. The population used is residents around the Jaya Sari tofu factory, Sari Abadi, UD Lancar Jaya, and LW in Karangploso District, Malang Regency. While the instruments for data collection are interview questionnaires and documentation. Based on the description of the results of public perceptions, the highest percentage of perceptions is the question indicator no. 15 of $93.3 \%$, which is about the need for socialization to the community about the use of water hyacinth plants and fish cultivation as an alternative to the use of tofu liquid waste.
\end{abstract}

Keywords: Attitudes, perceptions, management and utilization of tofu waste

\section{ANALISIS SITUASI}

Jumlah industry tahu di di wilayah Keacamatan Karangploso kurang lebih 20 industri tahu yang tersebar berbagai desa (Prayitno, Rulianah, \& Zamrudy, 2020). Menurut ( Ningrum et al., 2020) kedelai merupakan bahan baku yang digunakan untuk membuat tahu, dimana tersusun berbagai komponen antara lain: protein, karbohidrat, lemak dengan presentase antara 40-60\%, 25$50 \%$, dan $8-12 \%$, selian itu juga mengandung kalsium, besi, fosfor, dan juga vitamin. Selain menghasilkan makanan bergizi industri tahu juga berpeluang dalam penyerapan tenaga kerja, namun di sisi lain juga dapat berdampak negatif akibat air limbah dihasilkan yang berpotensi merusak lingkungan sekitar. Letak industri tahu yang dekat pemukiman penduduk, sehingga muncul permasalahan dengan warga sekitar. Banyaknya jumlah air yang digunakan pada proses pembuatan tahu menyebabkan limbah yang dihasilkan juga cukup besar (Dewa \& Idrus. 2017) .

Residu tahu, atau residu kedelai, merupakan produk sampingan utama yang berasal dari pembuatan tahu atau turunannya. Dilaporkan bahwa sekitar 14 juta ton RT dihasilkan setiap tahun di seluruh dunia (Huang et al., 2019). Bahan organik yang tinggi pada limbah tahu, dikarenakan bahan baku pembuatan tahu (kedelai) mengandung protein hingga $40-60 \%$ (Indah et al., 2014). akibat limbah tahu yang langsung dibuang ke sungai menyebabkan pencemaran, merusak habitat yang ada serta dapat menyebabkan estetika berkurang (Ramlan \& Sumihardi, 2018). Karakteristik limbah tahu yang ada perlu pengolahan dahulu sebelum di buang ke lingkungan (Nindra \& Hartini. 2015).

Industry tahu yang berada di desa Ngenep Kec. Karangploso Malang termasuk dalam industry kecil dan menengah. Industri kecil dan menengah termasuk sebagai industri dengan tingkat efisien energi rendah dengan tingkat pencemaran yang tinggi hal ini kurangnya dukungan atau tidak adanya sistem penanganan limbah secara optimal. Komposisi limbah cair tahu mengandung zat tersuspensi, sehingga mengakibatkan air menjadi kotor/keruh. Bau busuk pada air 
buangan industri tahu disebabkan adanya proses pemecahan protein yang mengandung sulfur atau sulfat tinggi oleh mikroba alam. Padatan yang terlarut tersebut menyebabkan tersuspensi sehingga merubah air menjadi keruh. Limbah cair tahu merupakan media yang sangat baik bagi pertumbuhan mikroorganisme. Seperti penelitian oleh ( Masangkay. 2012) bahwa Performa tahuwhey sebagai media cair di perbanyakan mycobacterium tuberculosis strain H37Rv.

Berdasarkan Keputusan Gubernur Jawa Timur Nomor 45 Tahun 2002 tentang baku mutu limbah cair untuk industri tahu dan kecap/tempe untuk volume limbah cair tahu maksimum per satuan bahan baku $20 \mathrm{~m}^{3} / \mathrm{ton}$ kedelai dari parameter BOD (Biological Oxygen Demand) kadar maximum(mg/l) 150, COD (Chemical Oxygen Demand) sebesar 300, TSS (Total Suspended Solid) sebesar 100, dan pH 6-9. Sementara menurut (Setyawati et al., 2019) Limbah cair tahu pada umumnya berupa bahan organik tinggi dan kadar BOD sebesar $997 \mathrm{mg} / \mathrm{L}$, COD sebesar $1247 \mathrm{mg} / \mathrm{L}$, dan TSS yang cukup tinggi sebesar 587,5 $\mathrm{mg} / \mathrm{L}$. oleh karena itu sebelum limbah dibuang ke perairan maka harus dilakukan sterilisasi agar sesuai dengan ketentuan baku mutu limbah cair. Hal ini agar Penerapan Undang-Undang Nomor 32 Tahun 2009 tentang Pengolahan Limbah Cair Tahu Jawa Perusahaan Perdagangan dapat diimplementasikan ( Enterprises et al. 2020).

Observasi awal yang dilakukan terhadap industri tahu yang berlokasi di Kecamatan Karangploso diantaranya industri tahu Jaya Sari, Sari Abadi, UD Lancar Jaya, dan UD LW ditemukan bahwa industri tahu tersebut merupakan industri milik perseorangan dan dengan skala industri rumah tangga. Limbah yang dihasil beberapa langsung dibuang keperairan. Hal ini menyebabkan keresahan bagi masyarakat sekitar terutama yang menggunakan fasilitas sungai secara langsung. Pelaksanaan produksi dilakukan sebagian besar menggunakan tenaga manusia dan masih secara tradisional. Hasil samping dari proses produksi pabrik tahu berupa limbah padat dan limbah cair. Air buangan industri tahu kualitasnya bergantung dari proses yang digunakan. Menurut (Herlambang, 2002), protein merupakan komponen terbesar pada limbah cair tahu sebesar 226,06-434,78 mg/l hal dapat menyebabkan kandungan nitrogen jika langsung dibuang perairan.

Saat ini, metode pengolahan konvensional tidak selalu efektif untuk menghilangkan seluruh kontaminan air. Salah satu alternative yang disarankan menggunakan teknik Fitoremediasi. Fitoremidiasi merupakan salah satu cabang dari bioremediasi yang menggunakan aplikasi tumbuhan untuk remediasi air limbah (Mustafa \& Hayder .2020) . Menurut (Ansari et al., 2020) bahwa Fitoremediasi perairan yang terkontaminasi melalui teknologi ramah lingkungan berdasarkan aplikasi makrofit akuatik. Menurut (Djo et al. 2014) Enceng gondok sangat berpotensi sebagai fitoremidiasi. Menurut (Mustafa \& Hayder, 2020) Studi terbaru tentang aplikasi tanaman gulma air dalam fitoremediasi air limbah. Masyarakat khususnya pengusaha tahu seharusnya mengetahui tentang pemanfaatan enceng gondok sebagai Pengolahan limah yang ramah lingkungan.

Berdasarkan latar belakang maka tujuan penelitian ini adalah: mendeskripsikan Persepsi masyarakat terhadap Pengelolaan Limbah Tahu dan Pemanfaatannya di Masyarakat Kec. Karangploso Kab. Malang

\section{METODE PELAKSANAAN}

Jenis pengabdian ini termasuk jenis pengabdian survey. Dimana memberikan gambaran secara mendetail tentang persepsi pengelolaan limbah tahu dan pemanfaatannya di masyarakat lingkungan pabrik tahu di kecamatan Karangploso Kabupaten Malang.

\section{Waktu dan Tempat Pengambilan Sampel}

Periode pengambilan mulai bulan Februari sampai bulan Mei 2021. Tempat pengambilan sampel industri tahu Jaya Sari, 
Sari Abadi, UD Lancar Jaya, dan LW di desa Ngenep kecamatan Karangploso Malang.

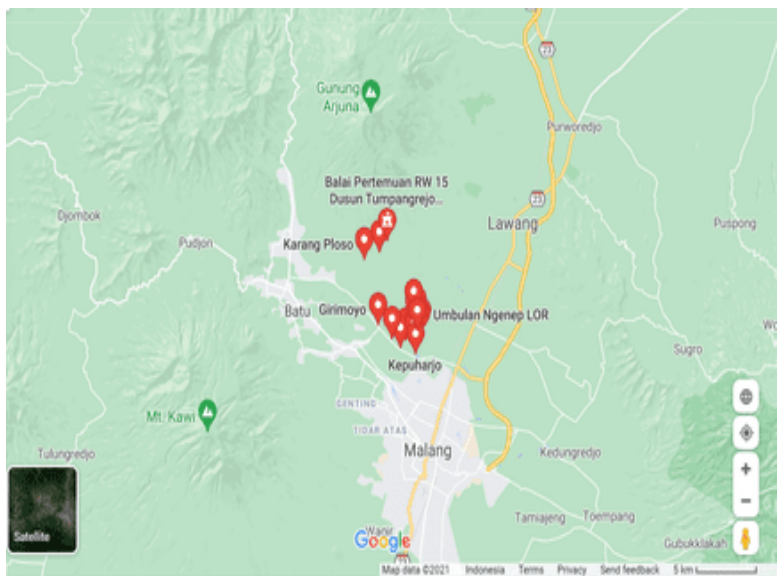

Gambar 1. Kecamatan Karangploso Malang

Populasi

Populasi dalam kegiatan ini masyarakat yang tingkal di sekitar industri tahu di desa Ngenep kecamatan Karangploso Malang. Pengambilan sampel dilakukan dengan accidental sampling di 4 lokasi. Jumlah sampel sebanyak 30 responden. Terdapat 15 pertanyaan yang terdapat dalam rubrik wawancara untuk persepsi masyarakat.

\section{Prosedur Pengabdian}

Dimulai dari observasi di lokasi pengabdian kemudian dilanjutkan dengan penetapan masalah dan pengambilan data Melalui penyebaran rubrik persepsi pengelolaan dan pemanfaatan limbah cair tahu di masyarakat.

\section{Teknik Analisis Data}

Hasil pengabdian dianalisis menggunakan statistic deskriptif untuk melihat persentase persepsi pengelolaan limbah tahu di masyarakat kecamatan Karangploso Malang.

\section{HASIL DAN PEMBAHASAN}

\section{A. Hasil Persepsi Masyarakat Terhadap Pengelolaan Limbah Tahu di Karangploso Malang}

Hasil deskripsi persepsi masyarakat yang terangkum dalam hasil rubrik wawancara dengan masyarakat. Ringkasan hasil deskripsi persepsi masyarakat dapat dilihat pada Gb.1 berikut.

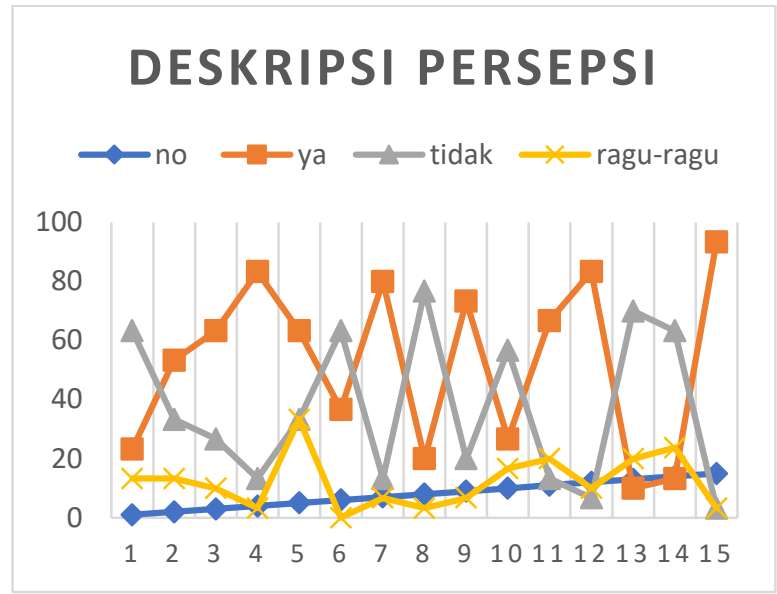

Gambar 1. Deskripsi Persepsi Masyarakat

Pengeloaan limbah cair ada beberapa yang langsung dibuang ke perairan, tetapi juga ada yang ditampung di bak penampungan sementara. Berikut gambar penampungan sementara limbah cair tahu yang ada di 4 lokasi pabrik tahu. Berikut gambaran pengelolaan limbah cair pada pabrik tahu di 4 UD pabrik tahu.

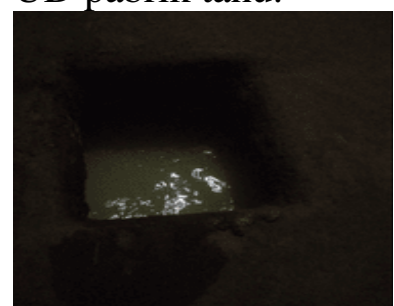

Gambar 2. UD Pabrik Tahu LW

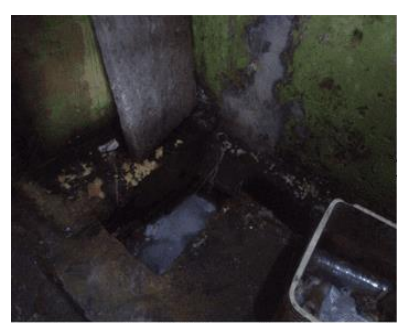

Gambar 3. UD Lancer Jaya

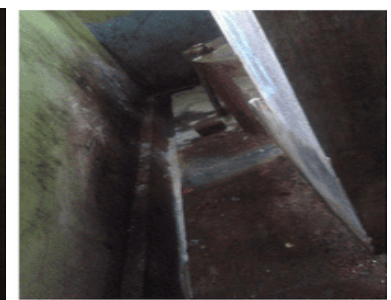

Gambar 3. UD Sari Abadi

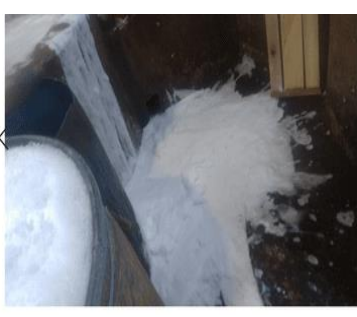

Gambar 3. UD Jaya Sari 
Untuk mengetahui persepsi masyarakat tim pengabdi memberikan survey yang berisi 15 pertanyaan dengan tiga pilihan jawaban yaitu: Ya, Tidak, dan Ragu-ragu. Sementara hasil deskripsi persepsi masyarakat terhadap pengelolaan dan Pengolahan limbah tahu dalam bentuk (\%) terdapat pada tabel 1 berikut.

Tabel 1. Hasil Persepsi Masyarakat dalam (\%)

\begin{tabular}{|c|c|c|c|c|}
\hline No & Pertanyaan & Ya & Tidak & ragu \\
\hline 1 & $\begin{array}{lr}\text { Apakah sebelumnya sudah } \\
\text { pernah ada Sosialisasi tentang } \\
\text { edukasiran } \\
\text { lingkungan? }\end{array}$ & 23,3 & 63,3 & 13,3 \\
\hline 2 & $\begin{array}{l}\text { Apakah sudah ada pengolahan } \\
\text { limbah cair tahu pada sentra } \\
\text { tahu tersebut? }\end{array}$ & 53,3 & 33,3 & 13,3 \\
\hline 3 & Apakah limbah cair tahu & & & \\
\hline 4 & $\begin{array}{l}\text { langsung dibuang ke sungai? } \\
\text { Apakah air sungai yang } \\
\text { tercemar limbah tahu mulai } \\
\text { berubah warnanya? }\end{array}$ & 63,3 & 26,7 & 3,3 \\
\hline 5 & $\begin{array}{l}\text { Apakah sungai yang tercemar } \\
\text { limbah tahu mulai berubah } \\
\text { baunya? }\end{array}$ & 63,3 & 33,3 & 33,3 \\
\hline 6 & $\begin{array}{l}\text { Apakah sungai tersebut masih } \\
\text { digunakan untuk aktifitas } \\
\text { masyarakat sekitar? }\end{array}$ & 36,7 & 63,3 & 0 \\
\hline 7 & $\begin{array}{l}\text { Apakah saudara mulai } \\
\text { terganggu dengan keberadaan } \\
\text { limbah cair tahu tersebut? }\end{array}$ & 80 & 13,3 & 6,7 \\
\hline 8 & $\begin{array}{l}\text { Apakah saudara merasakan } \\
\text { ganguan penyakit kulit setelah } \\
\text { menggunakan air sungai yang } \\
\text { tercemar limbah? }\end{array}$ & 20 & 76,7 & 3,3 \\
\hline 9 & $\begin{array}{l}\text { Apakah saudara melihat ada } \\
\text { biota yang mati disungai yang } \\
\text { tercemar limbah? }\end{array}$ & 73,3 & 20 & 6,7 \\
\hline 10 & $\begin{array}{l}\text { Apakah pemilik pabrik tahu } \\
\text { sudah pernah menyakan } \\
\text { keluhan ke saudara terkait } \\
\text { pengelolaan limbah tahu } \\
\text { tersebut? }\end{array}$ & 26,7 & 56,7 & 16,7 \\
\hline 11 & $\begin{array}{llr}\text { Apakah } & \text { menurut } & \text { saudara } \\
\text { perlu } & \text { ada } & \text { perbaikan }\end{array}$ & & & \\
\hline & $\begin{array}{l}\text { Pengolahan limbah pada } \\
\text { pabrik tahu tersebut? }\end{array}$ & 66,7 & 13,3 & 20 \\
\hline 12 & $\begin{array}{l}\text { Apakah perlu adanya } \\
\text { sosialisasi kepada pemilik } \\
\text { tahu tentang penanganan } \\
\text { limbah cair tahu yang ramah } \\
\text { lingkungan? }\end{array}$ & 83,3 & 6,7 & 10 \\
\hline 13 & $\begin{array}{l}\text { Apakah saudara tahu tentang } \\
\text { manfaat enceng gondok untuk } \\
\text { penangan limbah? }\end{array}$ & 10 & 70 & 20 \\
\hline 14 & $\begin{array}{l}\text { Apakah saudara tahu tentang } \\
\text { manfaat limbah cair untuk } \\
\text { budidaya ikan? }\end{array}$ & 13,3 & 63,3 & 23,7 \\
\hline 15 & $\begin{array}{l}\text { Apakah diperlukan adanya } \\
\text { sosialisasi ke masyarakat } \\
\text { tentang pemanfaatan tanaman } \\
\text { enceng gondok dan budidaya } \\
\text { ikan sebagai alternative } \\
\text { pemanfaatan limbah cair } \\
\text { tahu? }\end{array}$ & 93,3 & 3,3 & 3,3 \\
\hline
\end{tabular}

\section{B. Pembahasan}

Hasil wawancara dengan responden tentang persepsi pengelolaan dan pemanfaatan limbah tahu di masyarakat menunjukkan hasil bahwa air sungai tercemar limbah cair tahu dan mulai berubah warnanya sebesar $83 \%$. Salah satu penyebabnya adalah kurangnya pengetahuan dan pembinaan bagi pelaku industri tahu di wilayah tersebut. Seperti pendapat (Priantari et al., 2017) bahwa perilaku masyarakat mempengaruhi kualitas air. Jika hal ini tidak dihentikan, maka akan dapat menimbulkan efek negatif bagi lingkungan, baik perairan maupun udara, penyebabnya adalah air limbah tahu mempunyai karakteristik sangat berbau dan mempunyai kandungan bahan pencemar tinggi (Dewa \& Idrus, 2017). Untuk mengetahui kualitas air maka dapat dilihat dengan beberapa paramer, Parameter fisik yang diukur adalah suhu, konduktivitas dan salinitas, dan kuantitas kimia oksigen terlarut, dinyatakan sebagai persentase dan $\mathrm{mg}$ L-1 dalam air dan nilai pH (Ivanković et al., 2017).

Berdasarkan hasil rubrik wawancara bahwa terdapat $93,3 \%$ pentingnya sosialisasi tentang pemanfaatan enceng gondok sebagai media fitoremidiasi karena limbah tahu sulit diolah. Menurut (Wang et al., 2021) cairan limbah organik konsentrasi tinggi memiliki komponen yang kompleks dan pengolahannya sulit. Oleh karena itu perlu adanya alternative pengelolaan limbah tahu yang ramah lingkungan yang disarankan peneliti melalui fitoremidiasi. Penelitian oleh (Antoniadis et al., 2021) bahwa tanaman liar seperti Arrhenatherum elatius, Bromus inermis, Artemisia vulgaris, Achillea millefolium, Galium mollugo, Stellaria holostea, dan Silene vulgaris. A. vulgaris dapat efektif menurunkan limbah yang mengkontaminasi tanah. Beberapa penelitian lain terkait fitoremidiasi antara lain: (1) Menurut (Ningrum et al. 2020) menyatakan bahwa kemampuan eceng gondok menyerap unsur

Purwaning Budi L. - Deskripsi Persepsi Masyarakat Terhadap Pengelolaan Limbah Tahu Dan Pemanfataanya Di Kecamatan Karangploso Kabupaten Malang 
hara serta beberapa senyawa organic yang terdapat dalam limbah cair; (2). (Suardana. 2015) juga menyampaikan bahwa penurunan nilai BOD sampai 52\% dari nilai awal dengan perlakukuan penutupan $90 \%$ enceng gondok; (3) Penelitian oleh (Auchterlonie et al., 2021) tentang Potensi fitoremediasi eceng gondok: studi kasus dari bendungan Hartbeespoort, Afrika Selatan, bahwa enceng gondok dapat digunakan sebagai alat fitoremediasi untuk mitigasi eutrofikasi di perairan terbuka dan mungkin berpotensi untuk mengurangi mekar Microcystis; (4) penelitian oleh (Niu et al., 2021) bahwa fitoremidiasi melalui strategi pemotongan akar pada C. Argentia dapat menurunkan cemaran limbah cd.

Tidak semua pabrik tahu mempunyai bak penampungan limbah tahu sementara. Hal tersebut terlihat dari hasil wawancara dengan masyarakat sekitar. Akibat yang ditimbulkan jika tidak memiliki bak penampuang adalah sisa produksi berupa limbah cair langsung dibuang ke sungai. Bila dibiarkan, air limbah akan berubah warnanya menjadi cokelat kehitaman dan berbau busuk. Akibatnya responden sebesar 20\% mengatakan mengalami sakit gatal karena masih menggunakan sungai untuk beraktifitas. Seperti pernyataan oleh (Kaswinarni, 2007) jika limbah langsung dialirkan ke sungai yang terjadi air sungai tercemar dan jika sungai tersebut dipergunakan dapat menimbulkan gangguan kesehatan berupa penyakit gatal, diare, kolera, radang usus dan penyakit lainnya.

Produk sampingan ini mengandung sejumlah besar nutrisi yang terdiri dari protein, gula sederhana, oligosakarida, mineral, dan isoflavon kedelai (Chua \& Liu, 2019). Limbah tahu Melalui Pengolahan yang baik dapat dimanfaatkan untuk kepentingan manusia. Seperti penelitian oleh (Kim \& Lee, 2010) menunjukkan bahwa kombinasi limbah pengolahan tahu dan lumpur digester dianggap sebagai salah satu bentuk sampah organik yang paling menjanjikan untuk produksi H2 yang berkelanjutan. Selain digunakan sebagai sampah organic limbah cair tahu juga dapat dimanfaatkan untuk mengembangkan budidaya ikan. Seperti penelitian oleh (Muliadi et al., 2017) bahwa dengan pemberian limbah cair tahu memberikan pengaruh yang nyata pada perlakuan $\mathrm{C}(40 \mathrm{ml} / \mathrm{l})$ limbah cair tahu dan mempunyai rerata kepadatan populasi tertinggi yaitu $623.240,38 \mathrm{ind} / \mathrm{ml}$.

\section{KESIMPULAN}

Berdasarkan hasil penelitian dapat simpulkan bahwa kesimpulkan bahwa masyarakat sekitar pabrik tahu menginginkan pengelolaan limbah tahu yang ramah lingkungan, oleh itu diperlukan edukasi Pengolahan limbah tahu yang benar yaitu melalui Pengolahan limbah secara fitoremiasi dengan memanfaatkan tanaman. Selain itu berdasarkan hasil angket bahwa masyarakat memerlukan edukasi tentang pemanfaatan limbah tahu, mengingat minimnya pengetahuan akan pemanfaatan limbah tahu.

\section{DAFTAR PUSTAKA}

Ansari, A. A., Naeem, M., Gill, S. S., \& AlZuaibr, F. M. (2020). Phytoremediation of contaminated waters: An eco-friendly technology based on aquatic macrophytes application. Egyptian Journal of Aquatic Research, 46(4), 371-376. https://doi.org/10.1016/j.ejar.2020.03.00 2

Antoniadis, V., Shaheen, S. M., Stärk, H. J., Wennrich, R., Levizou, E., Merbach, I., \& Rinklebe, J. (2021). Phytoremediation potential of twelve wild plant species for toxic elements in a contaminated soil. Environment International, 146(106233), $1-14$. https://doi.org/10.1016/j.envint.2020.10 
6233

Auchterlonie, J., Eden, C., Byrne, M., Venter, N., \& Sheridan, C. (2021). The phytoremediation potential of water hyacinth: a case study from Hartbeespoort Dam, South Africa. South African Journal of Chemical Engineering, $\quad 21, \quad 0-15$. https://doi.org/10.1016/j.sajce.2021.03.0 02

Chua, J. Y., \& Liu, S. Q. (2019). Soy whey: More than just wastewater from tofu and soy protein isolate industry. Trends in Food Science and Technology, 91(November 2018), 24-32. https://doi.org/10.1016/j.tifs.2019.06.01 6

Dewa, R., \& Idrus, S. (2017). Identifikasi Cemaran Limbah Cair Industri Tahu Di Kota Ambon. Majalah BIAM, 13(2), 11. https://doi.org/10.29360/mb.v13i2.3544

Djo, Y. H. W., Suastuti, D. A., Suprihatin, I. E., \& Sulihingtyas, W. D. (2017). Fitoremediasi Menggunakan Tanaman Eceng Gondok (Eichhornia crassipes) Untuk Menurunkan COD dan Kandungan $\mathrm{Cu}$ dan $\mathrm{Cr}$ Limbah Cair Laboratorium Analitik Universitas Udayana. Cakra Kimia (Indonesian EJournal of Applied Chemistry), 6(2), 137-144.

Enterprises, T., Novindri, M. R., Hidayani, S., Lubis, E. Z., Studi, P., Hukum, I., Hukum, F., \& Area, U. M. (2020). Application of Law No. 32 of 2009 in Processing of Liquid Waste in Javanese Tofu Trading Enterprises (Case Study at the Factory to Know Javanese Trading Business). JUNCTO: Jurnal Ilmiah Hukum, 2(32), 60-67.

Huang, X., Zhao, J., Xu, Q., Li, X., Wang, D., Yang, Q., Liu, Y., \& Tao, Z. (2019). Enhanced volatile fatty acids production from waste activated sludge anaerobic fermentation by adding tofu residue. Bioresource Technology, 274, 430-438. https://doi.org/10.1016/j.biortech.2018.1 2.010
Indah, L. sari, Hendrato, B., \& Soedarsono, P. (2014). KEMAMPUAN ECENG GONDOK (Eichhornia sp.), KANGKUNG AIR (Ipomea sp.), DAN KAYU APU (Pistia sp.) DALAM MENURUNKAN BAHAN ORGANIK LIMBAH INDUSTRI TAHU (SKALA LABORATORIUM). DIPONEGORO JOURNAL OF MAQUARES, 3(1), 1-6.

Ivanković, A., Petrović, D., Ivanković, P., \& Majstorović, J. (2017). Monitoring of Water Salinity of the Lower River Neretva. International Journal of Energy and Environmental Science, 2(6), 136143.

https://doi.org/10.11648/j.ijees.2017020 6.13

Kaswinarni, F. (2007). Kajian Teknis Pengolahan Limbah Padat Dan Cair Industri Tahu (Studi Kasus Industri Tahu Tandang Semarang, Sederhana Kendal, dan Gagak Sipat Boyolali). In Universitas Diponegoro.

Kim, M. S., \& Lee, D. Y. (2010). Fermentative hydrogen production from tofu-processing waste and anaerobic digester sludge using microbial consortium. Bioresource Technology, 101(1 SUPPL.), S48-S52. https://doi.org/10.1016/j.biortech.2009.0 3.040

Masangkay, F. R. (2012). The performance of tofu-whey as a liquid medium in the propagation of mycobacterium tuberculosis strain H37Rv. International Journal of Mycobacteriology, 1(1), 4550.

https://doi.org/10.1016/j.ijmyco.2012.01 .010

Muliadi, A. S., Dewiyanti, I., Nurfadillah, N., \& Darussalam, K. (2017). Pengaruh Pemberian Limbah Cair Tahu Terhadap Pertumbuhan Tetraselmis sp . Effect Of Tofu Liquid Waste On The Growth Of. Jurnal Ilmiah Mahasiswa Kelautan Dan Perikanan Unsyiah, 2(April), 259-267.

Mustafa, H. M., \& Hayder, G. (2020). Recent studies on applications of aquatic weed

Purwaning Budi L. - Deskripsi Persepsi Masyarakat Terhadap Pengelolaan Limbah Tahu Dan Pemanfataanya Di Kecamatan Karangploso Kabupaten Malang 
plants in phytoremediation of wastewater: A review article. Ain Shams Engineering Journal, 12(1), 355-365. https://doi.org/10.1016/j.asej.2020.05.00 9

Nindra, D. Y., \& Hartini, E. (2015). Efektivitas tanaman teratai (Nympahea firecrest) dan eceng gondok (Eichhornia crassipes) dalam menurunkan kadar biochemical oxygen demand) pada limbah cair industri tahu. VISIKES: Jurnal Kesehatan Masyarakat, 14(2), 123-130.

https://publikasi.dinus.ac.id/index.php/v isikes/article/view/1197

Ningrum, Y. D., Ghofar, A., \& Haeruddin. (2020). Efektivitas Eceng Gondok ( Eichhornia crassipes ( Mart .) Solm ) sebagai Fitoremediator pada Limbah Cair Produksi Tahu. Maquares, 9(2), 97106.

Niu, H., Bian, C., Long, A., Wang, Z., Cao, M., \& Luo, J. (2021). Impacts of root pruning and magnetized water irrigation on the phytoremediation efficiency of Celosia argentea. Ecotoxicology and Environmental Safety, 211(111963), 18.

https://doi.org/10.1016/j.ecoenv.2021.11 1963

Prayitno, P., Rulianah, S., \& Nurmahdi, H. (2020). Pembuatan Biogas Dari Limbah Cair Tahu Menggunakan Bakteri Indigeneous. Jurnal Teknik Kimia Dan Lingkungan, 4(2), 90-95. https://doi.org/10.33795/jtkl.v4i2.141

Prayitno, Rulianah, S., \& Zamrudy, W. (2020). INDUSTRI TAHU DI SENTRA INDUSTRI TAHU TEGALPASANGAN - PAKIS MALANG Oleh : Juranl Abdimas, 7(2), 143-146.

Priantari, N. L. P. M., Budiarsa Suyasa, I. W., \& Windia, I. W. (2017). Persepsi Dan Perilaku Masyarakat Terhadap Air Limbah Yang Dihasilkan Dan Kualitas Air Tukad Rangda, Kota Denpasar, Provinsi Bali. ECOTROPHIC: Jurnal
Ilmu Lingkungan (Journal of Environmental Science), 11(2), 125. https://doi.org/10.24843/ejes.2017.v11.i 02.p03

Ramlan, J., \& Sumihardi. (2018). Sanitasi Industri Dan K3 (Edisi Tahu). Pusat pendidikan sumber Daya manusia Kesehatan, Kementerian Kesehatan Republik Indonesia.

Setyawati, H., LA, S. S., \& Andjar Sari, S. (2019). Penerapan Penggunaan Serbuk Biji Kelor Sebagai Koagulan Pada Proses Koagulasi Flokulasi Limbah Cair Pabrik Tahu Di Sentra Industri Tahu Kota Malang. Industri Inovatif: Jurnal Teknik Industri, 8(1), 21-31. https://doi.org/10.36040/industri.v8i1.66 9.

Wang, S., Liu, J., Pisupati, S. V., Li, D., Wang, Z., \& Cheng, J. (2021). Dispersion mechanism of coal water slurry prepared by mixing various highconcentration organic waste liquids. Fuel, 287(September), 119340. https://doi.org/10.1016/j.fuel.2020.1193 40 